University of Nebraska - Lincoln

DigitalCommons@University of Nebraska - Lincoln

2008

Description of Khamul, gen. n. (Hymenoptera: Chalcidoidea: Eurytomidae), with a hypothesis of its phylogenetic placement

Michael W. Gates

National Museum of Natural History, Washington, D. C., michael.gates@ars.usda.gov

Follow this and additional works at: https://digitalcommons.unl.edu/systentomologyusda

Part of the Entomology Commons

Gates, Michael W., "Description of Khamul, gen. n. (Hymenoptera: Chalcidoidea: Eurytomidae), with a hypothesis of its phylogenetic placement" (2008). USDA Systematic Entomology Laboratory. 71. https://digitalcommons.unl.edu/systentomologyusda/71

This Article is brought to you for free and open access by the Entomology Collections, Miscellaneous at DigitalCommons@University of Nebraska - Lincoln. It has been accepted for inclusion in USDA Systematic Entomology Laboratory by an authorized administrator of DigitalCommons@University of Nebraska - Lincoln. 


\title{
Description of Khamul, gen. n. (Hymenoptera: Chalcidoidea: Eurytomidae), with a hypothesis of its phylogenetic placement
}

\author{
M. W. GATES \\ Systematic Entomology Laboratory, USDA, ARS, PSI, c/o National Museum of Natural History, Washington, D. C. 20013-7012, USA. \\ E-mail:michael.gates@ars.usda.gov
}

\section{Table of contents}

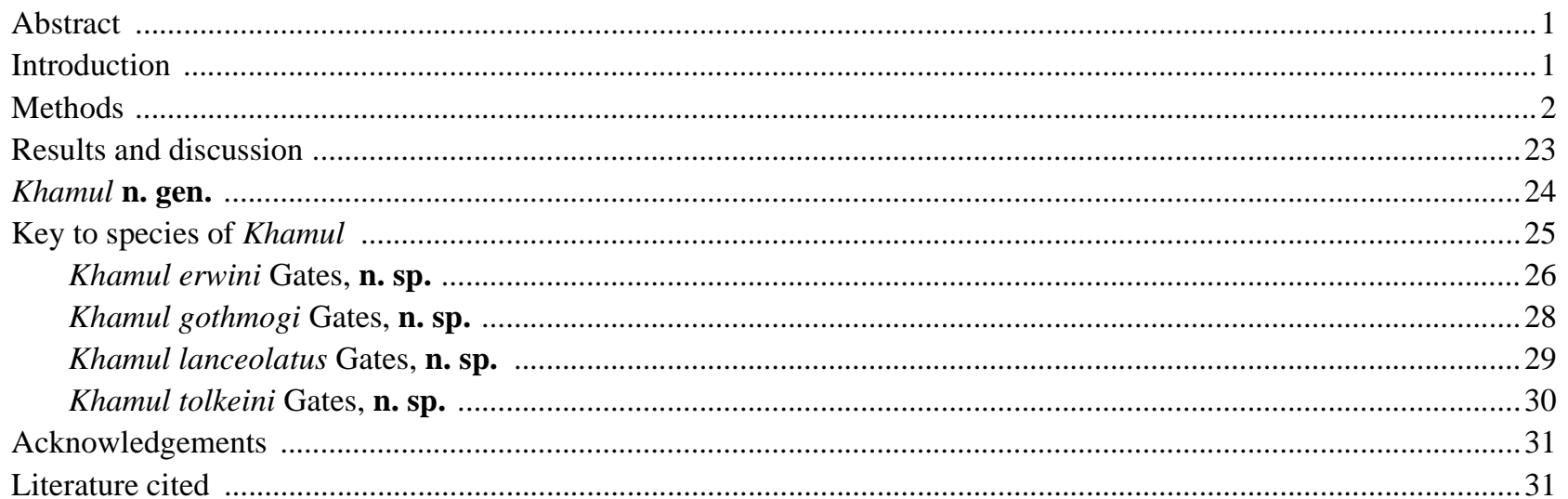

\begin{abstract}
Khamul n. gen., a distinctive eurytomid in the subfamily Eurytominae is described from the Neotropics based upon the type species, K. erwini, n. sp. A hypothesis of its phylogenetic placement within Eurytominae is presented, and four new species are described: K. erwini, K. gothmogi, K. lanceolatus, and K. tolkeini. Diagnostic features are included to distincguish this taxon from other eurytomines and a key to species presented. Its biology is unknown, but label data indicate walking stick eggs (Prisopus sp.; Phasmatodea: Prisopodidae) as a possible host.
\end{abstract}

Key words: Khamul, erwini, gothmogi, lanceolatus, tolkeini, Chalcidoidea, Eurytomidae, Eurytominae, systematics

\section{Introduction}

The biology, phylogeny, and diversity of the Eurytomidae (Hymenoptera: Chalcidoidea) have been discussed recently (Campbell et al. 2000, Gates \& Hanson 2006, Gates 2008, Lotfalizadeh et al. 2007). In this paper, I focus on the placement of a new genus described herein within the subfamily Eurytominae. As such, the primary goal is to assess the monophyly of the proposed new genus rather than to rework the large morphological phylogenetic treatment of Eurytominae recently put forward by Lotfalizadeh et al. (2007). Most eurytomines are primary or secondary parasitoids, but there are several strictly phytophagous genera. Those that are primary parasitoids typically attack eggs, larvae, or pupae of Orthoptera, Coleoptera, Diptera, and Hymenoptera (Goulet \& Huber 1993; DiGiulio 1997; Noyes 2003). The hyperparasitic eurytomines often 